\title{
Upshot of Various Transplanting Date and Nitrogen Doses on Growth and Yield of Tomato over Trichy Region of Tamil Nadu
}

\author{
P. Bhuvanaswri ${ }^{1 *}$, V. Geethalakshmi' ${ }^{1}$ T. Ragavan ${ }^{1}$, \\ V. Krishnamoorthy ${ }^{2}$ and T. Sivakumar ${ }^{3}$ \\ ${ }^{1}$ Department of Agronomy, ${ }^{2}$ Department of Horticulture, Agricultural College and Research \\ Institute, Madurai, Tamil Nadu, India \\ ${ }^{3}$ Department of Crop Physiology, TNAU, Coimbatore, Tamil Nadu, India
}

*Corresponding author

Keywords

Tomato,

Transplanting time, Yield

Article Info

Accepted:

12 February 2018

Available Online:

10 March 2018

\section{A B S T R A C T}

The current study was carried out to examine the effect of transplanting date on growth and fruit yield of tomato during rabi, 2016. The field experiment was conducted at Ponnaniyar, Trichy, Tamil Nadu. The experimental setup included a factorial randomized block design with three replications. The treatments comprised of four transplanting $\left(22^{\text {nd }}, 24^{\text {th }}, 26^{\text {th }}\right.$ and $28^{\text {th }}$ Meteorological Standard Week), and three N doses [RDN-75kg $\mathrm{ha}^{-1}, \mathrm{RDN}(-25 \%)$ and RDN (+25\%)]. The experimental results showed that different planting dates showed significant influence on growth and reproductive characters of tomato including fruit yield. The first transplanting date, resulted in improvement of all the attributes including fruit yield per hectare compared to $2^{\text {nd }}$ transplanting date. Therefore, it is suggested that earlier transplanting produced higher fruit yield of tomato.

\section{Introduction}

Tomato is very important throughout the world for both the fresh fruit market and processing. Tomato occupied 2.4 million hectares in the world with headship of Europe followed by Asia and America. Every year the production is around 4 million tons, but only $15 \%$ is produced in the tropics. This is mainly due to climate and to the production techniques which are not well developed. In the tropics, tomato is mainly grown during the cool season, because of the adverse conditions during summer which greatly affect productivity and quality. On the other hand, there is increasing evidence that the uses of poor cultural practices (especially the practice of $\mathrm{N}$ doses) as well as traditional cultivars and transplanting date are the main yield limiting factors. Yet, the improvement of yield through 
manipulation of $\mathrm{N}$ doses and ideal transplanting date is possible to achieve higher yield.

Tomato (Lycopersicon esculentum L.) is an annual herbaceous vegetable crop that comes under the family Solanaceae. It is believed to be the native of Western South America and often used as a nutritious edible fruit. The consumption of tomato shows an increasing trend over years because of its nutritional qualities. Its production is commonly affected due to adverse environmental conditions. Tomato, being a sensitive crop to moisture and temperature, it is often grown under greenhouse condition. The yield of tomato as an open field crop is found to show a weak positive correlation with the changing weather condition leading to remarkable yield loss. Accordingly, a better understanding is required of the factors that affect the growth and development of tomato. Hence the study is oriented to examine the influence of different planting dates on morphology and yield of tomato with the implementation of agricultural practices, to assess the interaction of weather over tomato productivity.

\section{Materials and Methods}

The experiment was carried out at farmer field, Ponnaniyar, of Thiruchirapalli district, Tamil Nadu during rabi, 2016. The place is located at $10.51^{\circ} \mathrm{N}$ latitude and $78.21^{\circ} \mathrm{E}$ longitude at an altitude of $78.17 \mathrm{~m}$ above Mean Sea Level (MSL). The place enjoys a moderate climate and receives a normal rainfall of $850.6 \mathrm{~mm}$ in a year with mean maximum and minimum temperature of $37.4^{\circ}$ $\mathrm{C}$ and $29.2^{\circ} \mathrm{C}$ respectively. The field soil is taxonomically 'Ustic', sandy loam in texture. The soil of has a $\mathrm{pH}$ of 7.98 which is mildly alkaline in with a normal EC $\left(0.24 \mathrm{dSm}^{-1}\right)$.

The trial was conducted using PKM-1 variety of tomato. The statistical design used for analysis is factorial concept of Randomized Block Design (RBD) with three replications. The treatment combination comprised of four dates of planting at fifteen days interval [November $1^{\text {st }}\left(\mathrm{D}_{1}\right)$, November $15^{\text {th }}\left(\mathrm{D}_{2}\right)$, December $1^{\text {st }}\left(D_{3}\right)$ and December $15^{\text {th }}\left(D_{4}\right)$ ] and three doses of nitrogen $\left[\mathrm{N}_{1}\right.$ : Application of $\mathrm{N}$ at recommended dose (RDN-75 kg ha ${ }^{-1}$ ), $\mathrm{N}_{2}$ : $-25 \%$ RDN and $\mathrm{N}_{3}:+25 \%$ RDN The combination of factors comprises of twelve treatments. Dimension of the plot is $4.0 \mathrm{~m} \mathrm{x}$ $3.0 \mathrm{~m}^{2}$. Protray were filled with the mixture of vermicompost and native soil. Each cells were dibbled with two seeds. The field was ploughed thrice with cultivator to obtain a fine tilth and was leveled uniformly and raised beds were formed. Twenty eight days old seedlings were transplanted to the main field with a spacing of $60 \mathrm{~cm} \mathrm{X} 40 \mathrm{~cm}$. During the research period, irrigation was given to the field using bore well water. The biometric observations on growth attributes was recorded on 45 and 90 DAT and the yield attributes were recorded at the time harvest.

\section{Results and Discussion}

As per the results shown in table 1 and 2, the main effects of planting date and nitrogen doses revealed significant variation with respect to growth, yield and yield attributes of tomato, but the interaction effect of different planting dates and nitrogen doses was nonsignificant.

\section{Effect of planting date on growth attributes}

Development in growth characters is considered as pre-requisite to increased yield of any crop. The higher plant height of (61.22 $\mathrm{cm}$ ) and number of branches per plant (8.09) was obtained from $1^{\text {st }}$ November $\left(D_{1}\right)$ planted crops (Table 1), which decreased considerably with each successive delay in planting date. Likewise the maximum dry matter production (45.48g) was observed in $D_{1}$ followed by $D_{2}$ 
$\left(15^{\text {th }}\right.$ November). It is therefore marked that early planted crops $\left(D_{1}\right.$ and $\left.D_{2}\right)$ performed better with induced normal vegetative growth, whereas the later dates were unfavorable for normal growth.

This is because of the positive climatic conditions that prevailed, particularly the higher temperature and optimum rainfall resulted in greater photosynthesis and higher mobilization of assimilates. The trend of present result is in agreement with the findings Islam et al., (2010) and Hamma et al., (2012) also observed that early planted crops performed better in terms of growth because the crop gets enough duration to complete the vegetative phase fully.
Effect planting dates on yield and yield attributes

The date of planting exhibited marked influence on yield components of tomato fruit. In the present study early planted crops $\left(D_{1} \&\right.$ $\mathrm{D}_{2}$ ) recorded significant higher number of fruits per plant $(18.69,16.96)$ similarly, the maximum individual fruit weight $(38.03 \mathrm{~g}$, $38.10 \mathrm{~g}$ ) was also noted in early planted crops (Table 2), with respect to fruit yield $\mathrm{D}_{1} \& \mathrm{D}_{2}$ significantly out yielded the rest of planting dates. Whereas, yield was recorded lowest in $15^{\text {th }}$ December $\left(\mathrm{D}_{4}\right)$, which indicated a deceased trends noticed towards later dates of planting and yield levels were much higher in earlier than later planted crops.
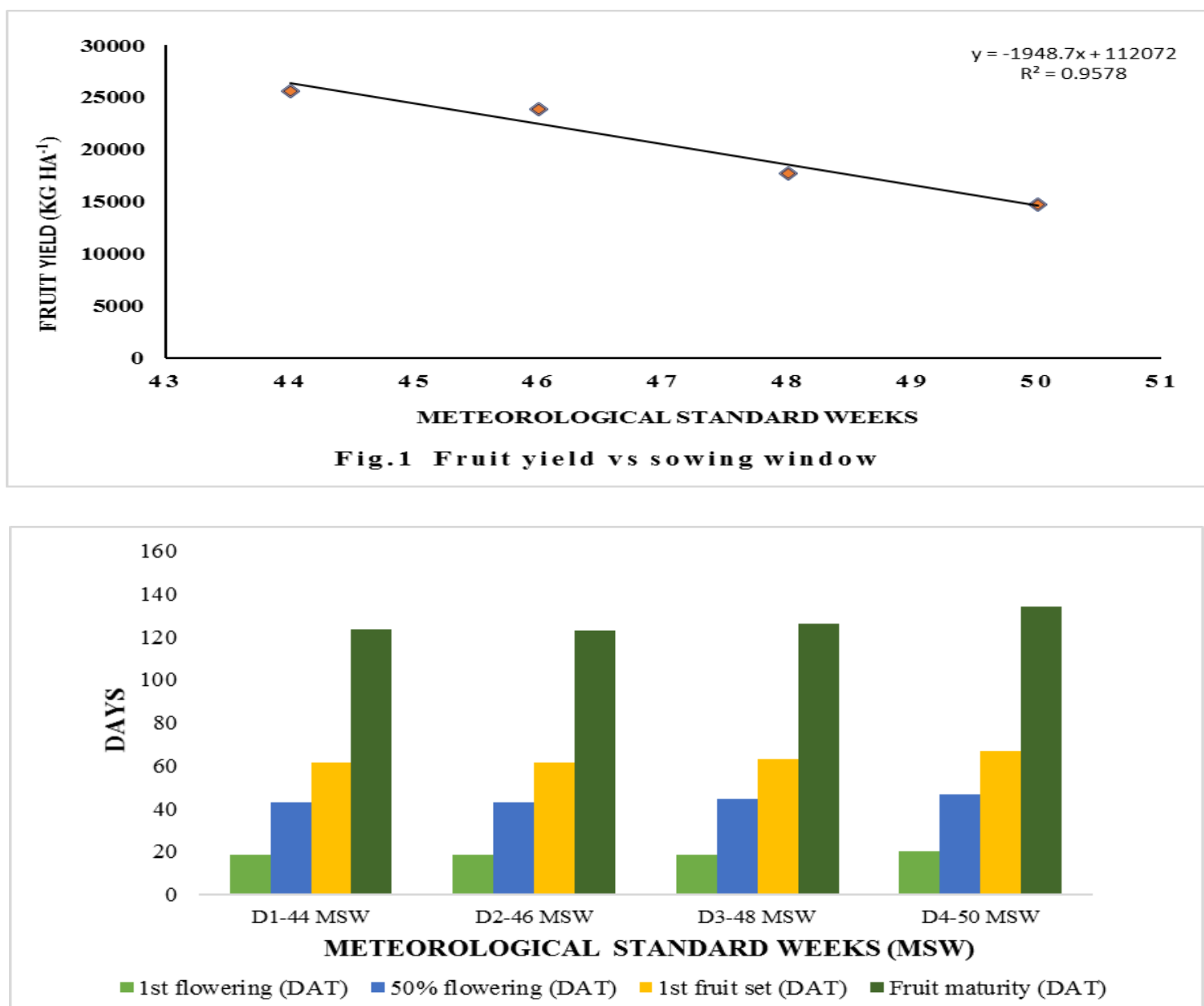

Fig.2 Duration of major phenophases of tomato 
Table.1 Influence of transplanting dates and $\mathrm{N}$ doses on crop growth

\begin{tabular}{|c|c|c|c|c|c|c|c|c|c|c|c|c|}
\hline \multirow[t]{2}{*}{ Treatments } & \multicolumn{4}{|c|}{ Plant height $(\mathbf{c m})$} & \multicolumn{4}{|c|}{ No. of branches (No./plant $\left.{ }^{-1}\right)$} & \multicolumn{4}{|c|}{ DMP $\left(g_{\text {plant }}{ }^{-1}\right)$} \\
\hline & $\mathbf{N}_{1}$ & $\mathbf{N}_{2}$ & $\mathbf{N}_{3}$ & Mean & $\mathbf{N}_{1}$ & $\mathbf{N}_{2}$ & $\mathbf{N}_{3}$ & Mean & $\mathbf{N}_{1}$ & $\mathbf{N}_{2}$ & $\mathbf{N}_{3}$ & Mean \\
\hline$D_{1}$ & 63.09 & 49.72 & 70.85 & 61.22 & 8.73 & 6.00 & 9.53 & 8.09 & 49.42 & 32.52 & 54.80 & 45.58 \\
\hline $\mathbf{D}_{2}$ & 55.18 & 45.30 & 68.33 & 56.27 & 7.53 & 4.27 & 8.60 & 6.80 & 41.89 & 33.54 & 50.83 & 42.08 \\
\hline $\mathbf{D}_{3}$ & 61.07 & 44.03 & 68.43 & 57.84 & 3.93 & 4.73 & 4.60 & 4.42 & 39.73 & 32.74 & 50.19 & 40.89 \\
\hline $\mathbf{D}_{4}$ & 52.98 & 50.91 & 57.73 & 53.88 & 3.80 & 3.60 & 5.07 & 4.16 & 43.49 & 27.01 & 44.98 & 38.49 \\
\hline \multirow[t]{2}{*}{ Mean } & 58.08 & 47.49 & 66.33 & & 6.00 & 4.65 & 6.95 & & 43.63 & 31.45 & 50.20 & \\
\hline & \multicolumn{2}{|c|}{ S Ed } & \multicolumn{2}{|c|}{$\mathrm{CD}(\mathrm{P}=\mathbf{0 . 0 5})$} & \multicolumn{2}{|c|}{ S Ed } & \multicolumn{2}{|c|}{$\mathrm{CD}(\mathrm{P}=\mathbf{0 . 0 5})$} & \multicolumn{2}{|c|}{ S Ed } & \multicolumn{2}{|c|}{$\mathrm{CD}(\mathrm{P}=\mathbf{0 . 0 5})$} \\
\hline D & \multicolumn{2}{|c|}{3.01} & \multicolumn{2}{|c|}{6.25} & \multicolumn{2}{|c|}{0.44} & \multicolumn{2}{|c|}{0.91} & \multicolumn{2}{|c|}{1.66} & \multicolumn{2}{|c|}{3.45} \\
\hline $\mathbf{N}$ & \multicolumn{2}{|c|}{2.61} & \multirow{2}{*}{\multicolumn{2}{|c|}{$\begin{array}{l}\text { NS } \\
\text { NS }\end{array}$}} & \multirow{2}{*}{\multicolumn{2}{|c|}{$\begin{array}{l}0.38 \\
0.76\end{array}$}} & \multicolumn{2}{|c|}{0.79} & \multicolumn{2}{|c|}{1.44} & \multicolumn{2}{|c|}{2.99} \\
\hline D X N & \multicolumn{2}{|c|}{5.22} & & & & & \multicolumn{2}{|c|}{ NS } & \multicolumn{2}{|c|}{2.88} & \multicolumn{2}{|c|}{ NS } \\
\hline
\end{tabular}

Table.2 Impact of transplanting dates and $\mathrm{N}$ doses on yield attributes and yield

\begin{tabular}{|c|c|c|c|c|c|c|c|c|c|c|c|c|}
\hline \multirow[t]{2}{*}{ Treatments } & \multicolumn{4}{|c|}{ Fruit number (No.Plant $\left.{ }^{-1}\right)$} & \multicolumn{4}{|c|}{ Fruit weight ( $\mathrm{g}_{\text {fruit }}{ }^{-1}$ ) } & \multicolumn{4}{|c|}{ Fruit yield $\left(\mathrm{kg} \mathrm{ha}^{-1}\right)$} \\
\hline & $\mathbf{N}_{1}$ & $\mathbf{N}_{2}$ & $\mathbf{N}_{3}$ & Mean & $\mathbf{N}_{1}$ & $\mathbf{N}_{2}$ & $\mathbf{N}_{3}$ & Mean & $\mathbf{N}_{1}$ & $\mathbf{N}_{2}$ & $\mathbf{N}_{3}$ & Mean \\
\hline $\mathbf{D}_{1}$ & 17.13 & 14.93 & 24.00 & 18.69 & 46.84 & 35.01 & 32.23 & 38.03 & 29816 & 19181 & 27827 & 25608 \\
\hline $\mathbf{D}_{2}$ & 16.87 & 13.80 & 20.20 & 16.96 & 44.87 & 33.75 & 35.67 & 38.10 & 27934 & 17287 & 26526 & 23916 \\
\hline $\mathbf{D}_{\mathbf{3}}$ & 12.53 & 8.93 & 15.53 & 12.33 & 45.53 & 27.65 & 29.54 & 34.24 & 21163 & 15075 & 16997 & 17745 \\
\hline $\mathbf{D}_{4}$ & 11.00 & 10.27 & 14.00 & 11.76 & 39.28 & 26.25 & 34.20 & 33.24 & 16236 & 9967 & 17818 & 14674 \\
\hline \multirow[t]{2}{*}{ Mean } & 14.38 & 11.98 & 18.43 & & 44.13 & 30.66 & 32.91 & & 23787 & 15378 & 22292 & \\
\hline & \multicolumn{2}{|c|}{ S Ed } & \multicolumn{2}{|c|}{$\begin{array}{c}\mathrm{CD}(\mathrm{P}= \\
\mathbf{0 . 0 5})\end{array}$} & \multicolumn{2}{|c|}{ S Ed } & \multicolumn{2}{|c|}{$\mathrm{CD}(\mathrm{P}=\mathbf{0 . 0 5})$} & \multicolumn{2}{|c|}{ S Ed } & \multicolumn{2}{|c|}{$\mathrm{CD}(\mathrm{P}=\mathbf{0 . 0 5})$} \\
\hline D & \multicolumn{2}{|c|}{1.08} & \multicolumn{2}{|c|}{2.24} & \multicolumn{2}{|c|}{1.51} & \multicolumn{2}{|c|}{3.12} & \multicolumn{2}{|c|}{1576} & \multicolumn{2}{|c|}{3269} \\
\hline $\mathbf{N}$ & \multirow{2}{*}{\multicolumn{2}{|c|}{0.94}} & \multicolumn{2}{|c|}{1.94} & \multirow{2}{*}{\multicolumn{2}{|c|}{1.30}} & \multicolumn{2}{|c|}{2.70} & \multirow{2}{*}{\multicolumn{2}{|c|}{1365}} & \multicolumn{2}{|c|}{2831} \\
\hline D X N & & & \multicolumn{2}{|c|}{ NS } & & & \multicolumn{2}{|c|}{ NS } & & & \multicolumn{2}{|c|}{ NS } \\
\hline
\end{tabular}

The production of fruit yield is controlled by various physiological and biochemical process that are involved in growth and development of crop. The potential yield of the crop is decided by appropriate sowing window as opined Singh et al., (1995). From the present investigation it was observed that crop transplanted on $1^{\text {st }}$ November resulted in increased fruit yield of 43 per cent higher over the crop planted on December $15^{\text {th }}$ (Fig. 1). It was also found that 7 per cent yield reduction was faced by the crop raised on $15^{\text {st }}$ November just a couple of week behind $1^{\text {st }}$ November, similarly 31 per cent yield reduction was faced by the crop raised on $1^{\text {st }}$
December. Further the per cent yield reduction still increases with delayed transplanting. Comparable results were evidenced by Tongova and Zhelev, 1975.

\section{Effect of transplanting dates on phenology}

The rate of crop development was stated to govern crop duration, which is of considerable importance in determining crop yields (Ellis et al., 1990). The phenophase results revealed that though much variation could not be observed, a slight increase in duration of early raised crops could be noticed (Fig. 2). Early planted crops attained the first 
flowering and 50 per cent flowering a little prior to the late planted crops. The instance was reverse in case of fruit set and maturity, where the late planted crops attained maturity before the early planted crops. Though it matured early, the fruit size and weight is much reduced with respect to late planted crops comparatively. Thereby the fruits produced from the late planted crops were not fit for marketable quality. Hence a mere shifting of transplanting date results in greater realization of higher remuneration by the farming community.

\section{Acknowledgement}

With at most pleasure and sincerity, the first author thankfully acknowledge Dr. V. Geethalakshmi for her support to undertake this study and also grateful to thank the NATCOM scheme for their economical support.

\section{References}

Ellis, R.H., Hadley, P. Roberts, E.H. and Summerfield, R.J. 1990. Quantitative relations between temperature and crop development and growth. In: Climatic change and plant genetic resources. London and New York, Belhaven Press. Pp. 85-112.

Hamma, I.L., Ibrahim, U. and Haruna, M. 2012. Effect of planting date and spacing on the growth and yield of sweet pepper (Capsicum annuum L.) in samara area of Zaria in Nigeria. Nigerian J. Agric. Food and Env. 8:6366.

Islam, M., Saha, S., Akand, H. and Rahim, A. 2010. Effect of sowing date on the growth and yield of sweet pepper (Capsicum annuum L.) Agronomski Glasnik.

Singh, D.N. and Tripanthy, P. 1995. Growth and yield of tomato genotypes and technology. Indian J. Agril. Sci. 65 (12): 863-865.

Tongova, E. and Zhelev, D. 1975. The effect of sowing date and transplanting age on the economic results from mid early greenhouse tomato production. Hort. Abst., 46(3): 2261.

\section{How to cite this article:}

Bhuvanaswri, P., V. Geethalakshmi, T. Ragavan, V. Krishnamoorthy and Sivakumar, T. 2018. Upshot of Various Transplanting Date and Nitrogen Doses on Growth and Yield of Tomato over Trichy Region of Tamil Nadu. Int.J.Curr.Microbiol.App.Sci. 7(03): 1565-1569. doi: https://doi.org/10.20546/ijcmas.2018.703.187 